\title{
ВПЛИВ ОХОЛОДЖЕНОГО ПОВІТРЯ НА УТРИМАННЯ СВИНОМАТОК 3 ПОРОСЯТАМИ
}

\author{
Волощук Василь Михайлович \\ доктор сільськогосподарських наук, член-кор. НААНУ \\ Інститут свинарства і агропромислового виробництва НААНУ \\ ORCID: 0000-0001-6980-1293 \\ E-mail: pigbreeding@ukr.net
}

Іванов Володимир Олександрович доктор сільськогосподарських наук, професор Інститут свинарства і агропромислового виробництва НААНУ

ORCID: 0000-0001-86537092

E-mail: vl-iva9008@ukr.net

Засуха Людмила Василівна

кандидат сільськогосподарських наук Інститут свинарства і агропромислового виробництва НААНУ

ORCID: 0000-0001-7481-1242

E-mail: ludmila10031985@gmail.com

Бордунова Ольга Георгї̈вна доктор сільськогосподарських наук, професор Сумський національний аграрний університет

ORCID: 0000-0002-7120-1040

E-mail: bordunova.olga59@gmail.com

Павленко Юлія Миколаївна

кандидат сільськогосподарських наук, доцент Сумський національний аграрний університет ORCID: 0000-0002-4128-122X

E-mail: jasjulia@ukr.net

Розроблено спосіб покращання комфорту підсисних свиноматок з поросятами великої білої і породи фрранцузької селекції за умов промислової технології свинокомплексу ТОВ «Агропрайм Холдинг». Згідно розробленого способу зниження температури в зоні фіксуючого боксу відбувається ступінчасте: за температури повітря в приміщенні $27^{\circ} \mathrm{C}$ вмикається система водяного зрошення, яка подає воду у вигляді крапель на тулуб свиноматки в області лопаток; за температури повітря в приміщенні $32^{\circ} \mathrm{C}$, подається вода у виеляді тоненької цівки на тулуб свиноматки в області лопаток. Застосування запропонованого способу сприяло збільшенню маси гнізда поросят у 28 днів на 9,5-10,5 кг порівняно з традиційною технологією і на 5,0-6,4 кг порівняно з системою мілкодисперсного розсіювання води. На промисловому підприємстві ТОВ ТОВ «Агроінд» Дніпропетровської області розроблена система охолодження повітря за рахунок використання теплової енергії землі. ї̈ сутність полягає у наступному. У приміщеннях для утримання тварин у підnідлоговому просторі проміж гнойовими ваннами на глибині одного метра було прокладено бетонні канали повітропроводи з поперечним перерізом 1 × 1 м, по яких проходить вхідне повітря. За рахунок теплової енергії землі воно охолоджується у теплу пору року і подається у камеру попередньої підготовки вхідного повітря де розміщуються радіатори - теплообмінники, через їх труби або прокачується холодна вода з артезіанської свердловини. Додатково на вході до камери попередньої підготовки вхідного повітря встановлено пристрій контролю температури та вологості, що дозволяє регулювати і вирівнювати ці показники перед подачею у підземні канали - повітропроводи. Подача попередньо підігрітого (охолодженого) у підземних каналах - повітропроводах за рахунок теплової енергії землі повітря $з$ низько розміщених по периметру приміщення вихідних отворів вентиляційної системи сприяє кращій сезонній стабілізації температури у приміщенні, ефрективнішому видаленню шкідливих речовин, поліпшенню мікроклімату, підвищенню комфортності утримання поголів'я і як наслідок покращенню виробничих показників.

Ключові слова: свиноматки, поросята, відгодівельний молодняк, продуктивність температура, охолодження, вентиляція, обладнання

DOl: https://doi.org/10.32845/bsnau.lvst.2020.1.6

Одним із проблемних питань при утриманні підсисних свиноматок $€$ температурний дискомфорт, який спостерігається влітку, особливо в період сильної спеки. Відомо, що в спекотні дні підсисні свиноматки реагують зниженням живої маси, апетиту, що негативно позначається

на їх молочності і як результат - на рості поросят. Сильна чутливість свиней до високих температур пов'язана з тим, що на шкірі свиней відсутні потові залози, що ускладнює віддачу тепла в навколишнє середовище при перегріванні тварин. Погіршення фрізіологічної адаптації. у свиноматок, 
спричиняє серцеву недостатність що може призвести тварин до загибелі.

За даними ряду дослідників температура вище 25 ${ }^{\circ} \mathrm{C}$ викликає дискомфорт, зменшення споживання корму (160 г/день $/{ }^{\circ} \mathrm{C}$ при температурі $25-30^{\circ} \mathrm{C}$ і 460 г/день $/{ }^{\circ} \mathrm{C}$ при температурі $30-35^{\circ} \mathrm{C}$ і веде до зниження відтворювальних якостей, збільшення інтервалу між відлученням і сервісперіодом [2].

Для зниження температури повітря в свинарникуматочнику у спекотні дні, використовують два шляхи: конвекційне і випаровуючи охолодження. Конвекційне охолодження організму відбувається за рахунок руху повітря щодо шкірного покриву тварини, а випаровуюче охолодження - за рахунок поглинання тепла водою, що випаровується $з$ поверхні тіла [5].

Для невеликих приміщень, а також для свинофрерм, які не мають можливості провести серйозну модернізацію системи вентиляції, застосовують локальну систему локального охолодження підсисних свиноматок «фреш ніс». Вона містить охолоджуючий калорифер, з'єднаний 3 підвісною магістральною вентиляційною трубою, від якої відходять повітропроводи, що спрямовують охолоджене повітря до передньої частини маточних станків де знаходиться годівниця [8].

Для конвекційного охолодження застосовують, в основному, тунельну вентиляцію, охолоджуючі панелі та випарні охолоджувачі повітря. Застосування даних способів інших системах вентиляції (припливно-витяжних, припливних 3 використанням шахтних вентиляторів і ін.) неефективне в силу незначної швидкості руху повітря. Крім того, конвекційний спосіб охолодження застосуємо для тих регіонів, де пікова денна температура відносно невелика. Якщо ж денна температура зовнішнього повітря досягає $30^{\circ}$ C і вище, необхідно використовувати додаткові системи охолодження.

Тому основним обладнанням для охолодження в тваринництві стали системи випарного типу, в основі роботи яких лежить принцип адіабатичного охолодження поглинання тепла рідиною, що випаровується. Дані системи існують у великій кількості різних модифікацій, які можна звести до двох типів: форсункові і касетні [4].

Данські фахівці форми «SKOV» розробили систему охолодження повітря високого тиску яка містить насосну станцію, фільтри, трубопроводи, форсунки та пульт керування. Принцип роботи системи дуже простий. У систему труб закріплених по стінах приміщення подається вода під високим тиском (60-70 атм). За допомогою спеціальних форсунок вода розсіюється в повітрі свинарського приміщення. Найдрібніші частинки води випаровуються в нагрітому повітрі приміщення, відбираючи тепло і охолоджуючи повітря [6, 7].

Наприклад, коли температура піднімається вище $27^{\circ} \mathrm{C}$, періодично вмикають систему мілко дисперсного розсіювання води. При правильно розрахованої і змонтованій системі охолодження високого тиску можна досягти зниження температури повітря в приміщенні на 4$10^{\circ} \mathrm{C}$.

За такої системи слід контролювати температуру і вологість повітря в зоні знаходження поросят, а також якість води. Практичний досвід пазав, що при використанні неякісної води форсунки швидко виходять 3 ладу.
Охолоджуючі панелі виготовляють із гофрованих целюлозно-паперових або синтетичних матеріалів і вставляють у бокові стіни. Повітря, яке надходить в приміщення зовні проходить через панелі інтенсивно охолоджується і зволожується, за рахунок води, яка постійно подається насосом на робочу поверхню. В результаті досягається зниження температури повітря до $7^{\circ} \mathrm{C}$ при швидкості повітря 1,5м/сек.

На відміну від системи охолодження повітря високого тиску охолоджуючі панелі менш вибагливі до якості води та простіші в експлуатації [3]. Їх виготовляють товщиною 10 або $15 \mathrm{~cm}$, що забезпечує максимальне охолодження при досить низьких витратах на обладнання та економному споживанні електроенергії. Один насос розрахований на 12 м зволожуючої панелі. Але така система встановлюється тільки за нового будівництва.

На зарубіжних свинофермах набуває поширення застосування двох-швидкісних охолоджувачів випарного типу, які встановлюють у бокових стінах свинарників. Однією з головних особливостей цих систем $€$ їх низьке енергоспоживання

Наприклад, на свинокомплекс ЗАТ фрірми «Агрокомплекс» Краснодарського краю застосували установку Breezair, яка забезпечує примусову подачу повітря 3 вулиці, одночасно охолоджуючи, очищаючи і зволожуючи його. Охолодження забезпечується за рахунок випаровування води при проходженні повітря через насичені водою фільтри.. При цьому щоб запобігти переохолодженню поросят, не потрібно подавати повітря безпосередньо на станкове обладнання. Використане повітря виходить назовні свинарника через вікна або вентиляційні люки [1].

Випарне охолодження, в силу своєї дешевизни і низької енерговитратності, $€$ поширеним способом охолодження приміщень для підтримки температурного комфорту. Однак, випарне охолодження вимагає постійного джерела води для випаровування, і ефективно тільки при низькій відносній вологості, що обмежує його ефективне застосування тільки зонами сухого клімату.

Керування роботою охолоджувачів може здійснюватися автоматично за допомогою відповідних термостатів і датчиків температури. Можуть також використовуватися датчики швидкості руху подається в приміщення повітря. Звичайно, мінімальний рівень необхідної вентиляції підтримується без участі датчиків. Тому метою цього дослідження було розробити системи охолодження свиней за умов утримання тварину в період спекотних температур.

Матеріали та методи досліджень. Дослідження проводили у два етапи. На першому етапі досліджували в плив розробленої системи мікроклімату на відтворювальні якості свиноматок генотипу Galaxy 900 французької компанії «Франс-Гібрид» та на відгодівлю їх нащадків за умов промислового підприємства ТОВ «Агроінд» Дніпропетровської області.

На другому етапі досліджували проводили дослідження впливу розробленої системи на підсисних свиноматок з поросятами великої білої і породи французької селекції за умов промислової технології свинокомплексу ТОВ «Агропрайм Холдинг».

Результати досліджень. На промисловому 
підприємстві ТОВ ТОВ «Агроінд» Дніпропетровської області нами розроблена система охолодження повітря за рахунок використання теплової енергії землі. ї̈̈ сутність полягає у наступному. У приміщеннях для утримання тварин у підпідлоговому просторі проміж гнойовими ваннами на глибині 1 м було прокладено бетонні канали повітропроводи з поперечним перерізом 1 х 1 м, по яких проходить вхідне повітря. За рахунок теплової енергії землі воно охолоджується у теплу пору року і подається у камеру попередньої підготовки вхідного повітря де розміщуються радіатори - теплообмінники, через їх труби або прокачується холодна вода з артезіанської свердловини. Додатково на вході до камери попередньої підготовки вхідного повітря встановлено пристрій контролю температури та вологості, що дозволяє регулювати і вирівнювати ці показники перед подачею у підземні канали повітропроводи рис.

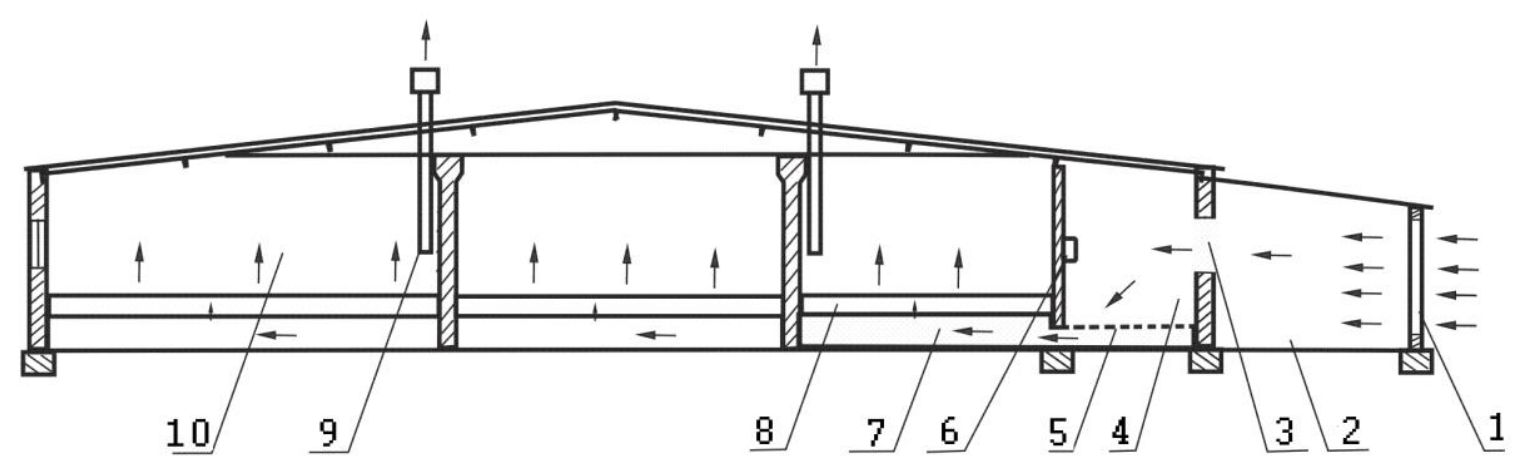

Рис. 1. Принципова схема роботи системи охолодження повітря за рахунок використання теплової енергії землі:

1- теплообмінник, 2-камера попередньої підготовки повітря, 3-отвір, 4-коридор,

5- коридорний підпідлоговий повітряний бетонний канал, 6-програмний регулятор з датчиками,

7-бетонні канали, 8-повітропроводи 9- витяжні вентилятори, 10-, приміщення.

За рахунок такого вирівнювання температура повітря, що надходить до приміщення становить залежно від пори року 21-27 ${ }^{\circ} \mathrm{C}$ проти $18-33^{\circ} \mathrm{C}$ без попередньої теплової підготовки. Зміна діапазону коливань температури вхідного повітря значно вплинула на інтенсивність росту поросят та рівень їх збереження (табл.1).

Таблиця 1

\section{Середньорічна економічна ефективність експериментальних розробок за результатами проведених дослідів}

\begin{tabular}{|l|c|c|c|c|c|c|}
\hline \multicolumn{1}{|c|}{ Показники } & \multicolumn{2}{c|}{ Підсисний період } & \multicolumn{2}{c|}{ Дорощування } & \multicolumn{2}{c|}{ Відгодівля* $^{\text {** }}$} \\
\cline { 2 - 7 } & $\mathbf{1}$ & $\mathbf{2}$ & $\mathbf{1}$ & $\mathbf{2}$ & $\mathbf{1}$ & $\mathbf{2}$ \\
\hline Кількість голів & 156 & 156 & 90 & 90 & 300 & 300 \\
\hline Кількість кормоднів & 4368 & 4368 & 4410 & 4410 & 34763 & 32851 \\
\hline Середньодобові прирости, г & 224 & 241 & 397 & 462 & 674 & 705 \\
\hline Збереженість поголів'я, \% & 89,3 & 91,0 & 92,1 & 94,0 & 97,7 & 98,4 \\
\hline Середня маса 1 голови, кг & 7,38 & 7,85 & 27,0 & 29,8 & 105,1 & 107,1 \\
\hline Сумарний приріст маси, кг & 836 & 923 & 1626 & 1857 & 30805 & 31616 \\
\hline Втрати внаслідок технологічного відходу, тис. грн & 1,86 & 1,62 & 4,9 & 3,5 & 19,6 & 13,2 \\
\hline${ }^{*}$ Собівартість 1 кг виробленої продукції, грн & 20,9 & 18,9 & 52,72 & 46,16 & 27,3 & 25,1 \\
\hline Закупівельна вартість виробленої продукції, грн./кг & 120 & 120 & 93 & 93 & 48 & 48 \\
\hline Загальні витрати на виробництво валової продукції, тис.грн. & 17,5 & 17,4 & 85,7 & 85,7 & 840,6 & 794,3 \\
\hline Валова вартість виробленої продукції, тис. грн. & 100,3 & 110,8 & 151,2 & 172,7 & 1478,6 & 1517,6 \\
\hline Чистий прибуток, тис. грн. & 82,8 & 93,4 & 65,5 & 87,00 & 638,0 & 723,3 \\
\hline
\end{tabular}

Примітка: * - собівартість і закупівельні ціни взяті середні за 2017 рік. Витрати та прибуток обраховано лише по дослідних групах з різною системою мікроклімату, без урахування загальних видатків на утримання всього поголів'я по господарству.

** - Цифрами 1 та 2 позначені приміщення з яких було взято тварин на відгодівлю: 1 - з боковою подачею повітря (контроль); 2 - $з$ нижньою подачею повітря (дослід).

3 метою покращання комфорту при утриманні підсисних свиноматок на ТОВ «Агропрайм Холдинг» Одеської області нами розроблено спосіб, згідно якого зниження температури в зоні фіксуючого боксу відбувається ступінчасто: при температурі повітря в приміщенні $27^{\circ} \mathrm{C}$, вмикається система водяного зрошення, яка подає воду у вигляді крапель на тулуб свиноматки в області лопаток; при температурі повітря в приміщенні $32^{\circ} \mathrm{C}$, вода у вигляді тоненького струмка подається на тулуб свиноматки в області лопаток (рис. 2). 


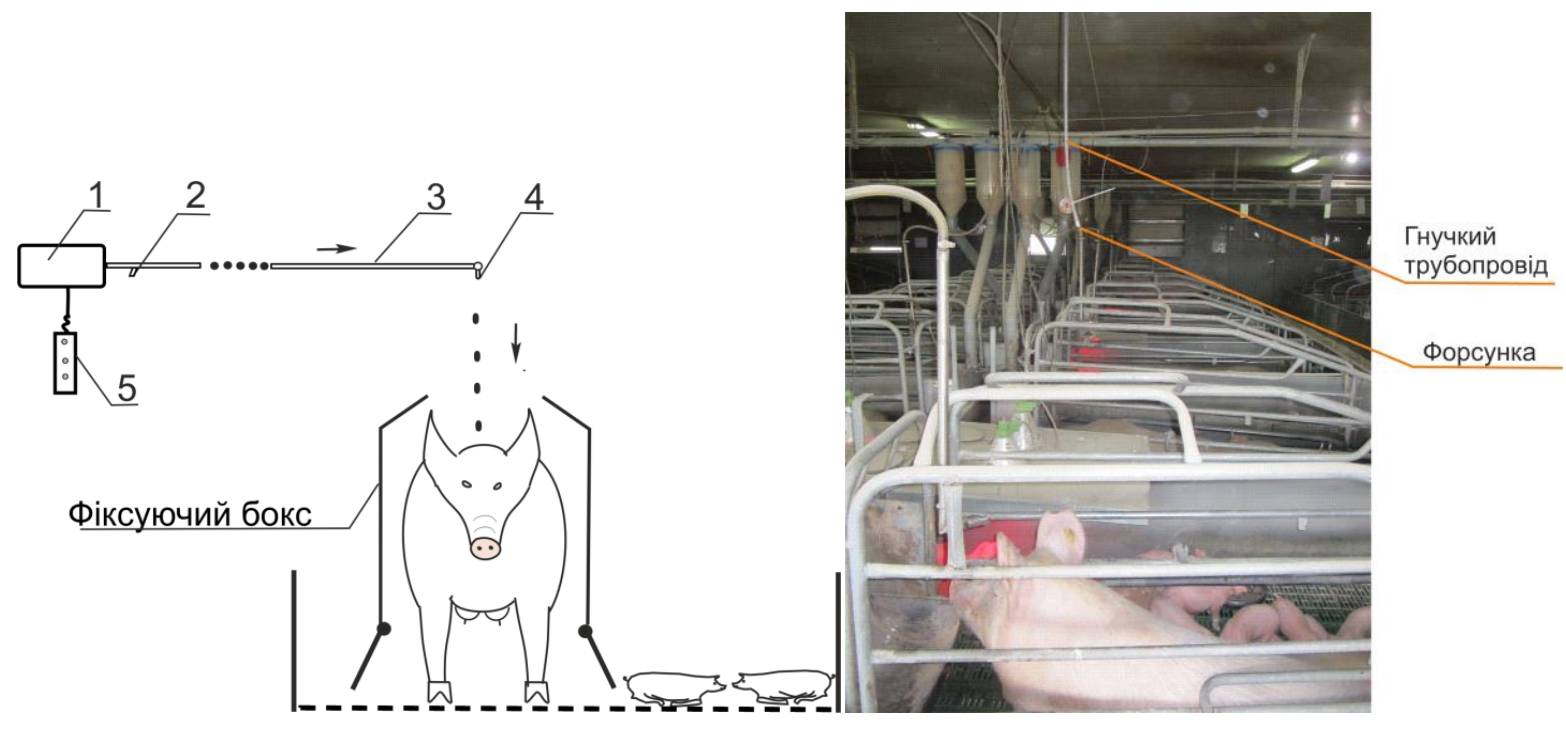

Рис. 2. Схема установки для охолодження підсисних свиноматок:

1- насос, 2 - фільтр, 3 - трубопровід, 4 - форсунка, 5 - пульт керування.

В умовах свинокомплексу (де температура зовнішнього повітря сягає більше $40^{\circ} \mathrm{C}$ ) проведено виробничий дослід, згідно якого сформували три групи підсисних свиноматок - одну контрольну та дві дослідні. Свиноматок контрольної групи в спекотні дні, коли температура в приміщенні досягала $27^{\circ} \mathrm{C}$, зрошували системою мілко дисперсного розсіювання води, а свиноматок першої дослідної групи зрошували водою у вигляді крапель. Причому краплі подавали на тулуб свиноматки в області лопаток.

Свиноматок другої дослідної групи при температурі повітря в приміщенні $32^{\circ} \mathrm{C}$, зрошували водою у вигляді струмка, який також подавали на тулуб свиноматки в області лопаток. Результати досліджень наведено в таблиці 2.

Спостереження показали, що свиноматки в умовах штучного туману (контрольна група) менше споживали корму порівняно із свиноматками дослідних груп (на 0,4-0,7 кг відповідно), які зрошувалися каплею і струмком. Це пов'язано з тим, що охолодження шкіри при зрошенні каплею і струмком відбувається краще. Так температура шкіри тулубу у свиноматок 1 і 2 дослідних груп була нижче на $5-7^{\circ} \mathrm{C}$, порівняно $з$ контрольною. Негативним моментом при охолоджені свиноматок штучним туманом $€$ те, що за таких умов поросята вкриваються вологою, що $\epsilon$ не відповідає зоогігієнічним вимогам. Позитивним моментом при зрошені краплею і струмком $€$ те, що охолодження тулубу відбувається в області серця та легень.

Таблиця 2

Відтворювальні якості свиноматок і деякі етологічні та клінічні показники за різних температурних умов

\begin{tabular}{|c|c|c|c|}
\hline \multirow{2}{*}{ Показник } & \multicolumn{3}{|c|}{ Група } \\
\hline & контрольна & дослідна 1 & дослідна 2 \\
\hline \multicolumn{4}{|c|}{$\mathrm{n}=16$ свиноматок в кожній групі, $\mathrm{t}=27^{\circ} \mathrm{C}$} \\
\hline Споживання корму, кг/добу & 5,5 & 5,9 & 6,2 \\
\hline Температура шкіри на тулубі ${ }^{\circ} \mathrm{C}$ & 35 & 30 & 28 \\
\hline Маса гнізда при відлученні, кг & $82,2 \pm 3,08^{* *}$ & $86,7 \pm 3,12$ & $92,7 \pm 3,72$ \\
\hline Збереженість поросят, \% & $91,5 \pm 2,1$ & $93,6 \pm 2,17$ & $94,7 \pm 3,33$ \\
\hline \multicolumn{4}{|c|}{$\mathrm{n}=16$ свиноматок, в кожній групі, $\mathrm{t}=32^{\circ} \mathrm{C}$} \\
\hline Споживання корму, кг/добу & 5,1 & 5,6 & 5,9 \\
\hline Температура шкіри на тулубі свиноматки, ${ }^{\circ} \mathrm{C}$ & 35 & 28 & 26 \\
\hline Маса гнізда при відлученні, кг & $80,2 \pm 3,28^{* *}$ & $84,7 \pm 3,62$ & $89,7 \pm 3,02$ \\
\hline Збереженість поросят, \% & $91,5 \pm 2,68$ & $92,6 \pm 2,47$ & $93,7 \pm 3,53$ \\
\hline
\end{tabular}

За таких умов у свиноматок 1 і 2 дослідних груп була вища маса гнізда (на 4-10 кг) при відлученні у 28 днів. Аналогічні дані отримані і в другому досліді.

Висновок. Запропоновані нові способи охолодження тварин порівняно з існуючими є досить ефективними, так як вони покращують температурний комфорт свиноматок i поросят та сприяють підвищенню відтворювальних й відгодівельних якостей молодняку. 


\section{Список використаної літератури:}

1.Использование аппаратов BREEZAIR на свинофермах в промышленных масштабах. [Електронний ресурс]. Режим доступу: https://agroserver.ru/articles/183.htm. (дата звернення 29.09.2020).

2.Мишуров Н.П., Кузьмина Т.Н. Энергосберегающееоборудование для обеспечения микроклимата в животноводческих помещениях. [Електронний ресурс]. - Режим доступу: https://www.twirpx.com/file/356832/. (дата звернення 29.09.2020).

3.Охлаждающие панели CoolPad RCP. [Електронний ресурc]. - Режим доступу: https://topixagro.com/catalog/ped-kuling/cool-pad-rcp-150-1800. (дата звернення 02.09.2020).

4. Пилипенко $€$. Температурний режим вирощування свиней і сучасні системи охолодження. [Електронний ресурс]. - Режим доступу: http://www.ait-magazine.com.ua/sites/defaultffiles/hs-stranicy-34-38.pdf. (дата звернення 02.09.2020).

5.Порівняння ефрективності систем охолодження свинарників. [Електронний ресурс]. - Режим доступу: http://pigua.info/uk/post/porivnanna-efektivnosti-sistem-oholodzenna-svinarnikiv. (дата звернення 04.09.2020).
6. Система охлаждения
SKOV.
[Електронний ресурс].
Режим
доступу: https://www.polnet.pl/ru/stado/podsvinki/mikroklimat/okhlazhdeniye/sistema-okhlazhdeniya-skov. (дата звернення 05.09.2020).

7. Система охлаждения воздуха распылением воды под большим давленим. [Електронний ресурс]. - Режим доступу: URL:https://agroclimate.com.ua/ru. (дата звернення 29.09.2020).

8.Сім способів боротьби з тепловим стресом свиноматок. [Електронний ресурс]. - Режим доступу: http://pigua.info/uk/post/sim-sposobiv-borotbi-z-teplovim-stresom-svinomatok-uk. (дата звернення 04.09.2020).

\section{References:} 29.09.2020].

1. Industrial use of BREEZAIR machines in pig farms. Available at: https://agroserver.ru/articles/183.htm. [Accessed:

2. Mishurov, N.P. and Kuz'mina, T.N., Energy-saving equipment for providing a microclimate in livestock buildings. Available at: $h$ https://www.twirpx.com/file/356832/. [ Accessed: 29.09.2020].

3. CoolPad RCP cooling pane/s. Available at: https://topixagro.com/catalog/ped-kuling/cool-pad-rcp-150-1800 [Accessed : 02.09.2020].

4. Pylypenko, Ye. Temperature conditions for pigs' growing and modern cooling systems. Available at: http://www.aitmagazine.com.ua/sites/defaultfiles/hs-stranicy-34-38.pdf. [Accessed: 02.09.2020].

5. Comparison of efficiency of pigsty cooling systems. Available at: http://pigua.info/uk/post/porivnanna-efektivnostisistem-oholodzenna-svinarnikiv. [Accessed: 04.09.2020].

6. SKOV cooling system. Available at: https:/www.polnet.pl/ru/stado/podsvinki/mikroklimat/okhlazhdenive/sistemaokhlazhdeniya-skov. [Accessed: 05.09.2020].

7. Air cooling system by spraying water under high pressure. Available at: URL:https://agroclimate.com.ua/ru. [Accessed: 29.09.2020].

8. Seven ways to deal with heat stress in sows. Available at: http://piqua.info/uk/post/sim-sposobiv-borotbi-z-teplovimstresom-svinomatok-uk. [Accessed: 04.09.2020].

Voloshchuk Vasily Mikhailovich, doctor of agricultural sciences Science, Corresponding Member NAASU, Institute of Pig Breeding and Agroindustrial Production of NAASU

Ivanov Vladimir Alexandrovich, Doctor of Agricultural Sciences, Professor,Institute of Pig Breeding and Agroindustrial Production of NAASU of NAASU

Zasukha Lyudmila Vasylivna, candidate of agricultural sciences, Institute of Pig Breeding and Agroindustrial Production

Bordunova Olga Georgievna, Doctor of Agricultural Sciences, Professor, Sumy National Agrarian University

Pavlenko Julia Nikolaevna, Candidate of Agricultural Sciences, Associate Professor, Sumy National Agrarian University

\section{Effect of cooled air on keeping sows with piglets}

A method has been developed to improve the comfort of suckling sows with piglets of Great White and French breeds in the conditions of the industrial technology of the pig-breeding complex of LLC "Agroprime". According to the developed method of reducing the temperature in the area of the fixing box, a stepwise process took place: at an air temperature in the room of 27 ${ }^{\circ} \mathrm{C}$, the water irrigation system was switched on, which supplied water in the form of drops to the sow's body in the area of the shoulder blades; at an air temperature in the room of $32{ }^{\circ} \mathrm{C}$, water was supplied in the form of a thin stream on the body of the sow in the area of the shoulder blades. The use of the proposed method contributed to an increase in the weight of the nest of piglets at 28 days by $9.5-10.5 \mathrm{~kg}$ compared with the traditional technology and 5.0-6.4 kg compared to the system of fine dispersion of water. At the industrial enterprise LLC "Agroind" in the Dnepropetrovsk region, an air cooling system was developed using the thermal energy of the earth. Its essence was as follows. In the premises for keeping animals in the underfloor space between the manure baths at a depth of $1 \mathrm{~m}$, concrete channels were laid - air ducts with a cross-section of $1 \times 1 \mathrm{~m}$, through which passed the incoming air. Due to the thermal energy of the earth, it was cooled in the warm season and was fed into the preliminary preparation chamber of the incoming air where radiators - heat exchangers were located, through their pipes or cold water was pumped from an artesian well. Additionally, a temperature and humidity control device was installed at the entrance to the incoming air preliminary treatment chamber, which made it possible to regulate and level these indicators before 
feeding into underground channels - air ducts. The supply of preheated (cooled) air in underground ducts - air ducts due to the thermal energy of the earth with air outlets of the ventilation system low located along the perimeter of the room - contributed to better seasonal temperature stabilization in the room, effective removal of harmful substances, improving microclimate, increased comfort of livestock keeping and as a result improving production performance.

Key words: sows, piglets, fattening young, productivity, temperature, cooling, ventilation, equipment.

Дата надходження до редакції: 02.02.2020 p. 
